\title{
Establishment of a new, secure colony of Endangered Bermuda Petrel Pterodroma cahow by translocation of near-fledged nestlings
}

\author{
NICHOLAS CARLILE, DAVID PRIDDEL and JEREMY MADEIROS
}

\begin{abstract}
Summary
Until recently, Bermuda Petrel Pterodroma cahow (IUCN Category: 'Endangered') bred only in sub-optimal habitat on four small islets in north-east Bermuda. Although intensive management of the population since 1962 has led to a substantial increase in population size (now approaching 100 pairs), the nesting habitat on these four islets is being increasingly inundated, eroded and destroyed by high seas associated with hurricanes and storms. To ensure the long-term conservation of the species a decision was made to establish a new colony at a more secure site on nearby Nonsuch Island, where they once bred in large numbers. Between 2004 and 2008, 104 near-fledged nestlings were translocated to artificial burrows on Nonsuch Island, where they were hand-fed meals of fish and squid. All but three translocated birds fledged successfully, with the first returning to Nonsuch Island in February 2008. The first Bermuda Petrel egg on Nonsuch Island in more than 300 years was laid in January 2009, and the resultant fledgling departed in June of the same year. By the end of the 2009/1o breeding season, a total of 18 Bermuda Petrels have been recorded on Nonsuch Island, 17 were translocated as near-fledged nestlings, and one bird came from the existing colonies. A total of five eggs have been produced, resulting in two fledglings. The establishment of this new colony, at a site that is much more secure than the existing nesting sites, greatly enhances the conservation prospects of the species and demonstrates the importance of translocation as a tool for the conservation of threatened seabirds.
\end{abstract}

\section{Introduction}

The Bermuda Petrel or Cahow Pterodroma cahow is endemic to the islands of Bermuda $\left(32^{\circ} 20^{\prime} \mathrm{N}\right.$, $64^{\circ} 45^{\prime} \mathrm{W} ; 53 \mathrm{~km}^{2}$ ) in the western North Atlantic Ocean. Colonisation by Europeans early in the $16^{\text {th }}$ Century severely depleted the bird's numbers (Butler 1619) and for more than 300 years the species was thought to be extinct. In 1951, a remnant population of 13-14 pairs was found nesting in rock cavities on three small rocky islets in north-east Bermuda (Murphy and Mowbray 1951). In 1961, a further survey of nearby islets found two more breeding sites and increased the known population to 18 pairs (Wurster and Wingate 1968, Madeiros 2005). A recovery programme began in 1962 (Wingate 1985), and by 2008, the breeding population had increased to 85 pairs (Madeiros et al. 2012). Despite this increase, the Bermuda Petrel remains one of the world's rarest seabirds and is classified as 'Endangered' (IUCN 2010).

In 2008, the Bermuda Petrel was restricted to four islets, having been extirpated from one islet by rats in 1967 (Madeiros et al. 2012). The four islets have a combined area of just 1.4 ha, are of low elevation $(<10 \mathrm{~m})$ and prone to being overwashed during hurricanes and storms. Composed of soft limestone, the islets are subject to severe erosion during storm activity. Soil occurs only in isolated pockets and vegetation is sparse. 
Historically, Bermuda Petrels nested in soil burrows (Zimmerman 1975) but the lack of soil at their current breeding sites has forced them to nest in deep rock cavities. Many of these cavities have needed to be reinforced or repaired and, over time, their limited number has been supplemented with artificial burrows constructed from concrete (Wingate 1978). Approximately $80 \%$ of the petrel population now breeds within these artificial structures. Difficulty of access to the islets makes the construction and maintenance of burrows a challenging and labour-intensive process. To date, this work has largely kept pace with the expansion of the population, but it is unlikely that this can be sustained. The increasing need for additional burrows as the population continues to grow exponentially (Madeiros et al. 2012) is exacerbated by the constant need to repair burrows damaged by storms, which have been particularly severe in recent years. Since 1989, at least seven major hurricanes have caused the sea to wash over the islets on which the petrels nest (Madeiros 2005). The most extensive damage was inflicted by hurricane Fabian when it hit Bermuda on 5 September 2003. This storm severely eroded each of the nesting islets and destroyed numerous burrows. Although the number of tropical storms worldwide has not changed for decades, they are growing larger and reaching higher maximum wind speeds. The power of hurricanes has almost doubled during the past 30 years, with strong evidence that this is due, at least in part, to human-induced global warming (Emanuel 2005). Accelerating storm damage and erosion is now regarded as the most serious threat to the continued survival of the Bermuda Petrel (Madeiros 2005).

Recent successes in establishing new colonies of burrow-nesting Procellariiformes (petrels and shearwaters) by translocation of near-fledged nestlings (Miskelly and Taylor 2004, Bell et al. 2005, Priddel et al. 2006, Miskelly et al. 2009) suggested that it would be possible to establish a new colony of Bermuda Petrel at a more secure site. A breeding population located on a much larger island that is far less susceptible to storm damage would significantly improve the longterm survival prospects for this species. Also, establishing a new colony at a site where the petrels can excavate soil burrows would reduce the need for management intervention and substantially lessen the workload associated with burrow maintenance.

This paper details the establishment of a new breeding colony of Bermuda Petrel on Nonsuch Island through the provision of artificial nest sites and the translocation of near-fledged nestlings.

\section{Methods}

Study site

Bermuda Petrel nests on four of the many islets fringing the eastern side of Castle Harbour: Horn Rock, Green Island, Inner Pear Rock and Long Rock (Figure 1). Nearby Nonsuch Island (6 ha) formerly supported a sizeable breeding population of Bermuda Petrel (Wingate 1985). It is thought to be one of the few "bird islands" mentioned by Strachy (1625) where early settlers would collect hundreds of birds every night for food. The petrel population on Nonsuch is likely to have declined through overharvesting but disappeared completely when the original vegetation was destroyed by clearing and overgrazing (Wingate 1985). A reforestation programme, initiated in 1963, has recreated extensive native forest cover (Wingate 1988). Black rats Rattus rattus were eradicated in the 1990s, but being only $180 \mathrm{~m}$ from the mainland, reinvasion is likely, so a network of bait stations is in place to eliminate new incursions.

The site chosen for the new colony on Nonsuch Island is a coastal hillside on the southern side of the island under forest dominated by bay grape Coccoloba uvifera, buttonwood Conocarpus erecta, Bermuda cedar Juniperus bermudiana, Bermuda palmetto palm Sabal bermudana and the introduced coastal she-oak Casuarina equisetifolia. The understorey is varied, but dominant plants include seaside oxeye Borrichia arborescens, Joseph's coat Euphorbia heterophylla, seaside goldenrod Solidago sempervirens and Saint Augustine grass Stenotaphrum secundatum. Twenty-four artificial burrows were installed; half were made of concrete, similar to those at existing colonies, and half were plastic and of the same design used for Gould's Petrel Pterodroma 


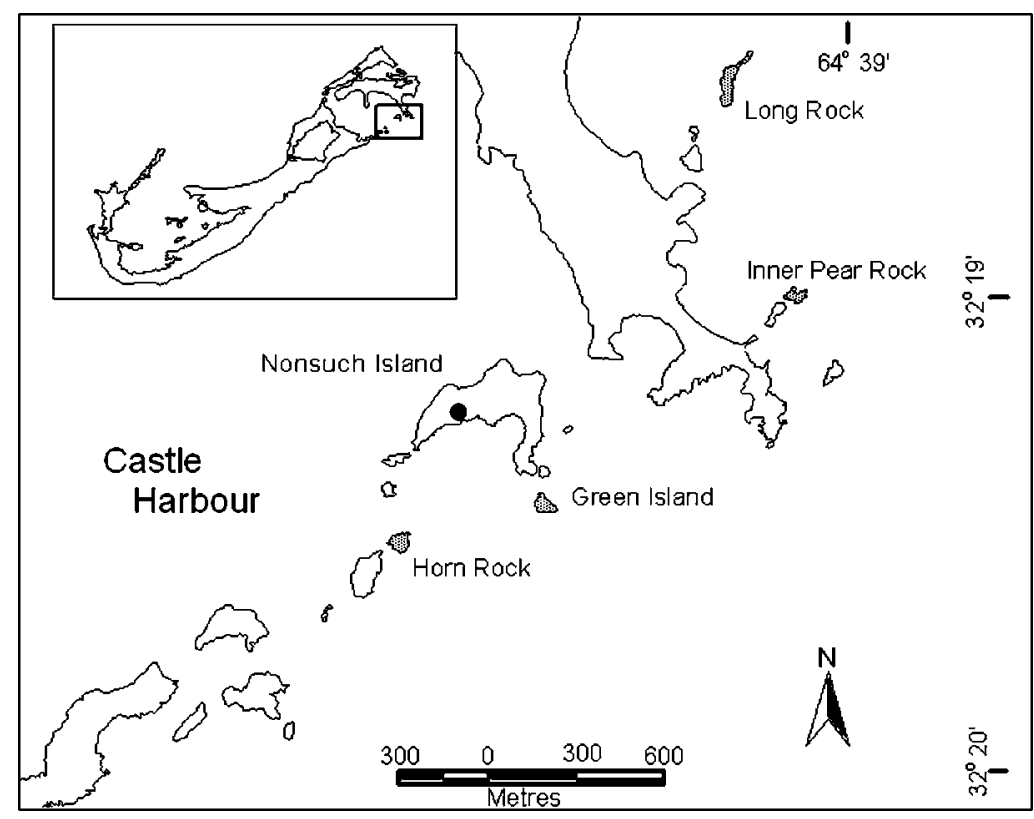

Figure 1. Castle Harbour, Bermuda, showing the four islets on which Pterodroma cahow currently breed (shaded), and Nonsuch Island, the site to which petrel nestlings were translocated. The translocation site on Nonsuch Island is indicated by the solid circle. The inset shows the location of the study area within the islands of Bermuda.

leucoptera (Priddel and Carlile 1995) but 40\% larger. In addition, five soil burrows were hand-dug, interspersed among the artificial burrows.

\section{Emergence and fledging}

The translocation procedure followed that used to establish a colony of Gould's Petrel on Boondelbah Island, Australia (Priddel et al. 2006). This technique was based on a pioneering study with Parkinson's Petrel Procellaria parkinsoni (Imber et al. 2003) and qualified successes with Fluttering Shearwater Puffinus gavia (Bell et al. 2005) and Common Diving-petrel Pelecanoides urinatrix (Miskelly and Taylor 2004). It relied on translocating nestlings before they first emerged from the burrow, the time at which it is believed that burrow-nesting seabirds first develop a strong philopatric attraction to their natal site. Prolonged hand-feeding of nestlings can result in poor fledging success (Miskelly and Taylor 2004), so the period of hand feeding was minimised by translocating nestlings as close as possible to the time of emergence (preferably less than six days). Selecting birds at the appropriate age or stage of development required knowledge of nestling growth. For Procellariiformes, the body measurement that provides the best indicator of time before fledging is wing length (Gangloff and Wilson 2004).

The Bermuda Petrel breeds during the northern winter (Madeiros et al. 2012). A single egg is laid in January within a terminal nest chamber in a burrow (a natural rock cavity or an artificial concrete burrow) and hatching occurs from mid-February to late March. Fledglings typically depart from mid-May to late June (Madeiros et al. 2012).

The breeding population of Bermuda Petrel has been monitored annually since 1961 (Madeiros et al. 2012). Since 2000/2001, all nest sites were visited regularly (1-4 days) from when adults first arrived to lay until all nestlings fledged. For nests that were either accessible or visible, the 
presence of adults, nests, eggs or nestlings was recorded at each visit. These data, together with the size and appearance of the nestling when first observed, were used to determine the date of hatching and age at fledging. Where burrows were so deep or convoluted that it was not possible to access the nest chamber, data were often incomplete.

As an adjunct to the ongoing monitoring, studies to gather information on emergence and ageing criteria were undertaken between 2001 and 2003. Early in May of each of these three years, all occupied and accessible nest sites were visited and any nestlings located were banded with a numbered metal leg-band. Sand was placed at the entrance to each burrow to detect the footprints of birds moving to or from the nest.

Each nest was then inspected every $1-2$ nights until all nestlings had fledged. Nestlings were weighed to the nearest gram using a spring balance, and wing length (flattened straightened wing chord) was measured to the nearest millimetre using a butt-end ruler. Emergence of nestlings from the burrow was detectable by tracks left in the sand, and often by the presence of down outside the burrow. The tracks of nestlings, typically directionless and concentrated around the burrow entrance, were distinguishable from the direct and purposeful passage of adults. The presence or absence of tracks was recorded immediately upon arrival at the site (shortly before sunset) and again immediately prior to departure (sometime after midnight). After each inspection, any tracks present were smoothed flat. From these observations, the date of first emergence of each nestling was determined.

Each burrow showing evidence of emergence was inspected for the presence of a near-fledged nestling. If the burrow was empty, the surrounding vicinity was also searched. Nestlings that could not be found at the sunset inspection were deemed to have fledged the previous night. Nestlings that were present at sunset but absent at midnight were deemed to have fledged that night. Fledging mass and wing length at fledging were taken as the last recorded measurements.

\section{Translocation of near-fledged nestlings}

The translocation of 104 nestlings to Nonsuch Island took place over five years (2004-2008). In 2004, I4 accessible near-fledged nestlings were randomly selected and translocated (approximately $60 \%$ of the cohort of 23). In each of the four subsequent years, about $80 \%$ of each cohort was translocated (range 21-25), with most non-translocated nestlings being in inaccessible nests. Nestlings were placed in a ventilated cardboard box and transported by boat the short distance (400-1,500 m) between donor and recipient sites during daylight. Up to five individuals were moved on any single day. On Nonsuch Island each bird was placed into either a concrete or plastic burrow within 30 minutes after their removal from the natal burrow. To prevent translocated nestlings from leaving their allotted burrow prematurely, a barrier was placed at the junction of the nest chamber and the burrow tunnel and left in place for 2-3 days. After removal of this barrier, small sticks were placed across the entrance to the burrow and monitored daily. Displaced sticks indicated that the nestling had emerged from the burrow. To evaluate the translocation procedure we examined emergence and fledging dates, fledging mass, wing length and return rates for translocated chicks in relation to those of non-translocated individuals.

\section{Feeding of translocated nestlings}

Measurements of nestling mass recorded during the 2002/3 breeding season were used to estimate feeding frequency and average meal size. An increase in weight between successive days was presumed to be associated with the nestling having been fed by one or more parents. For nestlings older than 70 days, feeds occurred approximately every two days and mean weight gain was $33 \mathrm{~g}$ (range 19-61 g, $n=10$ ). Due to digestion and defecation during the 24 -hour period between measurements, the recorded increase in mass was likely to underestimate actual meal size. Thus, translocated nestlings were fed on alternate days and nominal meal size was set initially at $40 \mathrm{~g}$. Fledging weight of the first cohort of translocated nestlings was below that of non-translocated nestlings (see Results) so in 
subsequent years nominal meal size was increased to $60 \mathrm{~g}$, and undersized nestlings were fed until they were satiated. Nestlings received meals until their wing length exceeded $250 \mathrm{~mm}$ or they no longer accepted food readily, indications that they were close to fledging. Nestlings were weighed before and after each feed, and weight change (i.e. meal size) was recorded.

Nestlings were fed with unprocessed squid and fish that were inserted into the proventriculus via the oesophagus. Fish were always fed whole, whereas the larger squid were sliced into manageable pieces. Squid, either California market squid Loligo opalescens or slender inshore squid L. plei, were purchased from local retail outlets. Fish, either Spanish sardine Sardinella anchovia, red-ear Sardine Harengula humeralis, Atlantic thread herring Opisthonema oglinum or hog-mouth Anchoa choerostoma fry (2004 only), were obtained from catches intended to supply the Bermuda Aquarium Museum and Zoo. The fry used in 2004 were too small to feed individually and so were packed inside squid mantles.

\section{Audio attraction}

The use of taped calls to attract prospecting conspecifics can be an important adjunct to translocation in successfully establishing new petrel colonies (Miskelly et al. 2009). A solar-powered audio system (Murremaid Music Box, Bremen, Maine, USA) broadcasting Bermuda Petrel vocalisations had been installed on Horn Rock in 2004, to attract new breeders to an area where there were some relatively secure unused nest sites. This system was moved to the translocation site on Nonsuch Island in late 2007, although it failed to function properly until repairs were effected in February 2008. The system was automated and operated only during the hours of darkness.

\section{Returning birds}

Monitoring of the colony site on Nonsuch Island to locate returning birds commenced in the 2007/8 breeding season and continued throughout each subsequent season. Visits, both at night and during the day, were undertaken sporadically but approximately twice weekly. During each visit all nest boxes and artificial burrows were inspected for the presence of a bird, and the area searched for signs of birds having been present (faeces, feathers and diggings). At night, the area was also searched to locate birds on the surface. All birds captured were checked for the presence of a leg band.

\section{Temperatures within artificial burrows}

The necessary use of artificial burrows on Nonsuch Island introduced the possibility that temperatures in these artificial structures were higher than in natural burrows, particularly for late-fledging petrels still ashore at the onset of summer. So we compared the summer temperatures inside two types of artificial burrow with those inside soil burrows. One of three $\mathrm{max} / \mathrm{min}$ thermometers was placed within each type of burrow (soil, concrete and plastic) during 12-29 May and 8-14 June 2004. Maximum and minimum temperatures were recorded daily, and the three thermometers reset and moved to a new burrow. Internal burrow temperatures were compared among burrow types and with ambient temperatures recorded concurrently at Bermuda International Airport, $2.3 \mathrm{~km}$ to the north-west.

\section{Statistical analysis}

Single factor ANOVA was used to test whether the measured parameters differed among years (2001-2003), among cohorts of translocated individuals (2004-2008), or between translocated and non-translocated birds (2004). Parameters included: dates of emergence and fledging; the duration between emergence and fledging; and age, mass and wing length at fledging. Significant results were compared using Student-Newman-Keuls range tests (Zar 1974). Single factor ANOVA and 
Student-Newman-Keuls range tests were also used to compare temperatures between burrow types. Data are presented as means \pm one standard deviation unless stated otherwise.

\section{Results}

\section{Emergence and fledging}

During the three years (2001-2003) before birds were translocated, nestlings emerged from their burrow between 14 May and 24 June, and fledged between 23 May and 30 June (Table 1 ). There was no difference among years in either the date of emergence $\left(F_{2,74}=2.052, P=0.136\right)$, the date of fledging $\left(F_{2,74}=2.003, P=0.142\right)$ or the period between emergence and fledging $\left(F_{2,74}=1.285\right.$, $P=0.283)$.

The period between emergence and fledging was 2-12 days (Table 1 ). Thus, to translocate nestlings shortly before they first emerged from the burrow we aimed to select nestlings approximately $14-18$ days prior to fledging. The relationship between wing length $(\mathrm{WL})$ and age (AGE expressed as days before fledging) was linear: $\mathrm{WL}=3.884 \mathrm{x}$ AGE $+259.33\left(r^{2}=0.962\right)$. Predicted wing length at 18 days before fledging was $189 \mathrm{~mm}$. Thus, nestlings selected for translocation were measured regularly and transferred when their wing length exceeded $189 \mathrm{~mm}$.

\section{Translocation of nestlings}

Of the 104 nestlings translocated to Nonsuch Island, three failed to fledge successfully (Table 2). In 2006, one fledgling was found dead at the shoreline of the island. A post-mortem examination revealed a skeletal deformity of the elbow that would have prevented the bird from flying. Two translocated nestlings (one each in 2007 and 2008) succumbed to an undiagnosed gastrointestinal ailment that caused them to refuse or regurgitate all food offered. Two additional nestlings (one each in 2004 and 2006) were grossly underweight and failed to meet the criteria for translocation, but in an effort to increase their survival prospects they were translocated and then fed until satiated each time. All these five birds are included in the total number translocated (Table 2) but excluded from all statistical calculations and analyses.

Nestlings were $67-89$ days old when translocated to Nonsuch Island. They fledged 4-20 days later, after receiving 2-10 meals, and first emerged from their burrow $2-13$ days before fledging. Means for each year (2004-2008) are shown in Table 2. There was no significant difference among years in fledging dates $\left(F_{4,98}=0.140, P=0.97\right)$ but, compared to subsequent years (2005-2008), fledglings in 2004 were younger $\left(F_{4,98}=4.087, P<0.01\right)$, lighter $\left(F_{4,98}=14.177\right.$, $P<$ 0.01), had shorter wings $\left(F_{4,98}=3.496, P=0.01\right)$ and experienced a longer period between

Table 1. Date of emergence, date of fledging and the duration between emergence and fledging for nontranslocated Bermuda Petrel nestlings (2001-2003).

\begin{tabular}{|c|c|c|c|c|}
\hline & \multicolumn{3}{|l|}{ Year } & \multirow[t]{2}{*}{ Total } \\
\hline & 2001 & 2002 & 2003 & \\
\hline Date of emergence (range) & 19 May - 24 June & 16 May - 15 June & 14 May - 12 June & 14 May - 24 June \\
\hline Date of emergence (median) & 30 May & I June & 27 May & 3o May \\
\hline Date of fledging (range) & 25 May - 30 June & 24 May - 25 June & 23 May - 20 June & 23 May - 30 June \\
\hline Date of fledging (median) & 5 June & 5 June & 4 June & 5 June \\
\hline $\begin{array}{l}\text { Days between emergence } \\
\text { and fledging (range) }\end{array}$ & $2-11$ & $3-12$ & $3-10$ & $2-12$ \\
\hline $\begin{array}{l}\text { Days between emergence } \\
\text { and fledging (mean } \pm \text { SD) }\end{array}$ & $5.6 \pm 2.6$ & $6.8 \pm 3.5$ & $6.5 \pm 2.1$ & $6.3 \pm 2.7$ \\
\hline Sample size & 27 & 21 & 29 & 77 \\
\hline
\end{tabular}


Table 2. Translocation date and age; fledging date, age, mass, and wing length; days to emergence; and meal size of Bermuda Petrel nestlings translocated to Nonsuch Island (2004-2008).

\begin{tabular}{lcccccc}
\hline & \multicolumn{1}{l}{ Year } & & & \multicolumn{2}{c}{ Total } \\
\cline { 2 - 5 } & 2004 & 2005 & 2006 & 2007 & 2008 & \\
\hline Nestlings translocated & 14 & 21 & 21 & 25 & 23 & 104 \\
Nestlings fledged & 14 & 21 & 20 & 24 & 22 & 101 \\
Median translocation date & 22 May & 20 May & 17 May & 20 May & 19 May & 19 May \\
Mean age at translocation (days) & 77 & 81 & 78 & 76 & 80 & 78 \\
Median fledgling date & 3 June & 31 May & 31 May & 3 June & 2 June & 1 June \\
Mean age at fledging (days) & 89 & 92 & 91 & 92 & 93 & 92 \\
Mean mass at fledging (g) & 231 & 302 & 281 & 306 & 279 & 285 \\
Mean wing length at fledging (mm) & 250 & 257 & 257 & 257 & 257 & 256 \\
Mean days emergence to fledging & 7 & 4 & 5 & 5 & 4 & 5 \\
Mean meal size (g) & 41 & 54 & 59 & 72 & 59 & 59 \\
\hline
\end{tabular}

${ }^{\mathrm{A}}$ One undersized individual omitted from all statistical calculations.

emergence and departure $\left(F_{4,98}=6.789, P<0.01\right)$. The translocated fledglings of 2004 were also younger $\left(F_{1,20}=8.462, P=0.009\right)$ and lighter $\left(F_{1,17}=13.357, P=0.002\right)$ than nontranslocated birds of the same cohort (Table 3 ), but did not differ in wing length or time between emergence and fledging $\left(F_{1,17}=0.107, P=0.748 ; F_{1,21}=0.533, P=0.473\right.$ respectively $)$.

Those nestlings from the 2005 to 2008 cohorts that were not translocated to Nonsuch Island were mostly in inaccessible nests. Consequently, data on non-translocated birds in these years are limited (Table 3) and insufficient to undertake meaningful comparisons among years or between translocated and non-translocated individuals.

\section{Returning birds}

Bermuda Petrels were first observed over Nonsuch Island in February 2008, conducting nocturnal aerial courtship flights. Up to six birds were observed at any one time. During the next few months, four birds were found ashore, three associated with artificial burrows and the fourth on the surface at night. Twelve birds were found ashore during the 2008/9 breeding season, and 16 in 2009/10. Overall, 18 individuals have been recorded on Nonsuch Island, of which only one has not been seen in the year or years subsequent to their first arrival. Of the 18 birds that have returned to Nonsuch, 17 had been translocated there as near-fledged nestlings; the other was a non-translocated bird that fledged on Inner Pear Rock. The fledging weight of translocated birds that have returned (mean $290 \mathrm{~g}$, range 209-375 g) was not significantly different to that of translocated birds that have not returned (mean $283 \mathrm{~g}$, range $188-369 \mathrm{~g})\left(F_{1,98}=0.556, P=0.458\right.$ ).

Seven birds that were translocated to Nonsuch Island have been recorded back on one of the existing four nesting islets. These birds spent $4-8$ days on Nonsuch Island before emerging, periods

Table 3. Fledging date, age, mass and wing length of non-translocated Bermuda Petrel nestlings (2004-2008). Due to nestling mortality or missing data from inaccessible nests not all parameters were obtained for all nestlings. Figures in parentheses indicate sample size.

\begin{tabular}{lcccccc}
\hline & \multicolumn{1}{l}{ Year } & & & \multirow{2}{*}{ Total } \\
\cline { 2 - 5 } & 2004 & 2005 & 2006 & 2007 & 2008 & \\
\hline Nestlings monitored & 10 & 2 & 3 & 7 & 6 & 28 \\
Median fledgling date & 10 June (9) & 10 June (2) & 2 June (3) & 2 June (7) & 6 June (4) & 6 June (25) \\
Mean fledging age (days) & $93(9)$ & $91(1)$ & $91(1)$ & $88(7)$ & $90(2)$ & $91(20)$ \\
Mean fledging mass (g) & $280(6)$ & $308(2)$ & $278(1)$ & $302(7)$ & $285(4)$ & $291(20)$ \\
Mean fledging wing length (mm) & $252(6)$ & $247(2)$ & $257(2)$ & $252(7)$ & $255(4)$ & $253(21)$ \\
\hline
\end{tabular}


that were not significantly different from those of birds that did return to Nonsuch (mean 7 days, range $2-11$ days) $\left(F_{1,23}=0.898, P=0.354\right)$.

2004 cohort

To date, four of 14 translocated birds (29\%) and four non-translocated birds (44\%) from the 2004 cohort have returned, but only one of these, a translocated bird, has returned to Nonsuch Island. On II November 2007, during the period of prospecting and courtship, a translocated bird was captured on Horn Rock after being coaxed to the ground at night using spotlights and noise ('war-whoops', Tennyson and Taylor 1990). Horn Rock was not the origin of this bird, which had hatched on Long Rock before being transferred to Nonsuch Island. Later that season, a pair of translocated individuals from the 2004 cohort was discovered on Horn Rock, sharing incubation duties. Both birds had hatched on Green Island. The nest on Horn Rock had been prepared the previous year but the occupants not identified. It is assumed that the two translocated birds had first returned to Horn Rock the previous year.

2005 cohort

To date, 12 translocated birds (57\%) from the 2005 cohort have returned, eight to Nonsuch Island and four to their natal islet. Three non-translocated birds (43\%) from the 2005 cohort have also returned. Two birds returned to Horn Rock where they originated, and one that fledged on Inner Pear Rock returned to Nonsuch Island, pairing with a bird of the same cohort that was translocated to Nonsuch from Green Island. The distance between Inner Pear Rock and Nonsuch is approximately $1.5 \mathrm{~km}$.

2006 cohort

To date, six translocated birds (30\%) but no non-translocated birds (of 5 individuals) from the 2006 cohort have returned, all to Nonsuch Island.

2007 cohort

To date, two translocated birds ( $8 \%$ ) from the 2007 cohort have returned to Nonsuch Island and one non-translocated bird (13\%) has returned to Horn Rock, where it fledged.

\section{Return rates}

The cumulative rate of return for non-translocated fledglings ranges from $6 \%$ at three years after fledging to $59 \%$ at eight years after fledging (Table 4 ). The return rate of translocated birds is greater than the return rate of non-translocated birds in all years other than six years after fledging (Tables 4

Table 4. Cumulative number of non-translocated Bermuda Petrel fledglings that have returned by $2009 / 2010$. Parentheses indicate the single non-translocated bird that recruited to the translocation site on Nonsuch Island.

\begin{tabular}{|c|c|c|c|c|c|c|c|c|c|c|}
\hline \multirow[t]{2}{*}{ Cohort } & \multirow[t]{2}{*}{$n$} & \multicolumn{8}{|c|}{ Years after fledging } & \multirow[t]{2}{*}{$\%$ returned } \\
\hline & & 1 & 2 & 3 & 4 & 5 & 6 & 7 & 8 & \\
\hline 2003 & 33 & $\mathrm{O}$ & $\mathrm{O}$ & 3 & 6 & 14 & 16 & 16 & & 48.5 \\
\hline 2004 & 9 & $\mathrm{O}$ & $\mathrm{O}$ & 1 & 1 & 3 & 4 & & & $44 \cdot 4$ \\
\hline 2006 & 5 & $\mathrm{O}$ & $\mathrm{O}$ & $\mathrm{O}$ & $\mathrm{O}$ & & & & & 0.0 \\
\hline 2007 & 8 & $\mathrm{O}$ & $\mathrm{O}$ & 1 & & & & & & 12.5 \\
\hline 2008 & 4 & $\mathrm{O}$ & $\mathrm{O}$ & & & & & & & 0.0 \\
\hline 2009 & 29 & $\mathrm{O}$ & & & & & & & & 0.0 \\
\hline 2010 & 34 & & & & & & & & & 0.0 \\
\hline
\end{tabular}


Table 5. Cumulative number of translocated Bermuda Petrel fledglings that have returned by $2009 / 2010$. Parentheses indicate numbers of returned birds that have returned to one of the four existing breeding islets, not Nonsuch. Dashes indicate that no searches were made for returning birds.

\begin{tabular}{|c|c|c|c|c|c|c|c|c|}
\hline \multirow[t]{2}{*}{ Cohort } & \multirow[t]{2}{*}{$n$} & \multicolumn{6}{|c|}{ Years after fledging } & \multirow[t]{2}{*}{$\%$ returned } \\
\hline & & 1 & 2 & 3 & 4 & 5 & 6 & \\
\hline 2004 & 14 & - & - & $2(2)$ & $3(3)$ & $3(3)$ & $4(3)$ & 28.6 \\
\hline 2005 & 21 & - & o & 4 & $9(1)$ & $12(4)$ & & 57.1 \\
\hline 2006 & 20 & o & o & 5 & 6 & & & 30.0 \\
\hline 2007 & 24 & o & o & 2 & & & & 8.3 \\
\hline 2008 & 22 & o & o & & & & & 0.0 \\
\hline Total & 101 & o & o & 13 & 18 & 15 & 4 & 0.0 \\
\hline$n$ & & 66 & 87 & 79 & 55 & 35 & 14 & 23.8 \\
\hline$\%$ returned & & 0.0 & 0.0 & 16.5 & 32.7 & 42.9 & 28.6 & \\
\hline
\end{tabular}

and 5). Data from this year are derived solely from the 2004 cohort. The return rate of birds translocated in 2004 is lower than expected, whereas the return rates for birds translocated in 2005 and 2006 are higher than expected. Based on return rates for other cohorts, we would have expected another two or three translocated individuals from the 2004 cohort to have returned by now.

\section{Breeding activity}

Translocated petrels first returned to Nonsuch Island during the $2007 / 8$ breeding season, but not until the following year did breeding actually occur. The first egg was laid on 26 January 2009, both members of the pair having been translocated to Nonsuch as nestlings in 2005. The egg, the only one laid on Nonsuch that year, hatched on 20 March 2009 and the nestling fledged successfully on 6 June 2009. The same pair also produced a fledgling the following year. These two fledglings are the only progeny to have been produced by the colony on Nonsuch Island thus far. Three additional eggs were laid during the 2009/1o season, but all failed to hatch.

Of the seven translocated birds that have returned to the original breeding islets, three have successfully raised a fledgling and two have produced eggs that failed to hatch. Although these birds have bred more successfully than those on Nonsuch, at least two have paired with older birds.

\section{Burrow temperatures}

Maximum temperatures within plastic $\left(25^{-29}{ }^{\circ} \mathrm{C}\right)$ and concrete burrows $\left(24-30^{\circ} \mathrm{C}\right)$ were similar to ambient temperatures $\left(24-31^{\circ} \mathrm{C}\right)$, whereas those inside soil burrows $\left(23-28^{\circ} \mathrm{C}\right)$ were, on average, 2-3 degrees cooler $\left(F_{3,88}=22.003, P<0.001\right.$, Figure 2a). Minimum temperatures were similar for all burrow types $\left(21-26{ }^{\circ} \mathrm{C}\right)$ but, on average, $2-3$ degrees warmer than ambient $\left(19-24{ }^{\circ} \mathrm{C}\right)$ $\left(F_{3,88}=16.323, P<\right.$ 0.001, Figure $\left.2 b\right)$.

\section{Discussion}

Of the 104 Bermuda Petrel nestlings translocated to Nonsuch Island all but three fledged. Similarly high fledging success has been achieved in other recent seabird translocations of nestlings. For example, of the 200 Gould's Petrel nestlings translocated to Boondelbah Island, $98 \%$ fledged successfully (Priddel et al. 2006). Although overall fledging success for 334 Fluttering Shearwaters translocated to Maud Island was $82 \%$, fledging success exceeded $90 \%$ in all but one year (Bell et al. 2005). Miskelly et al. (2009) reported eight other translocations of small and mediumsized Procellariiformes with fledging successes of $93-100 \%$. These various translocations collectively demonstrate that near-fledged nestlings can be translocated successfully with little or no reduction in fledging success. 


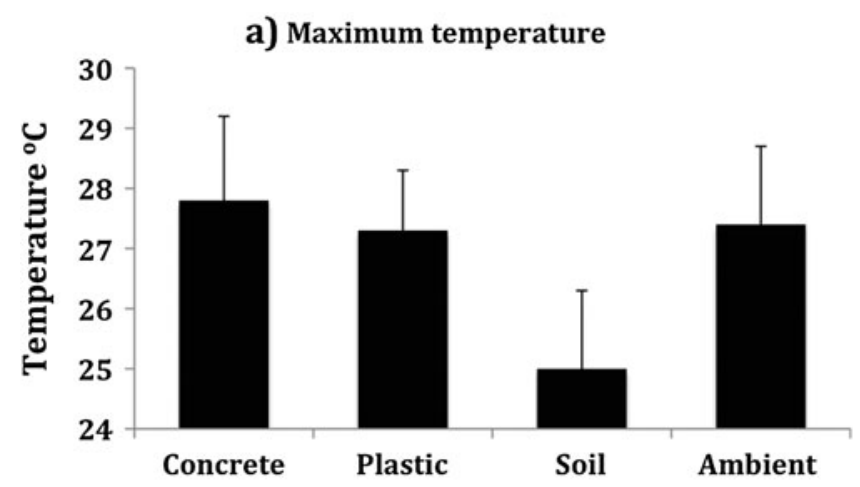

b) Minimum temperature

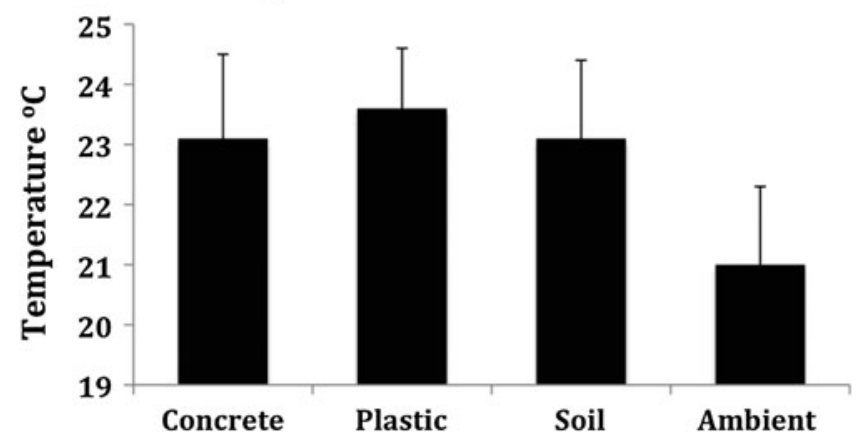

Figure 2. Mean daily maximum (a) and minimum (b) temperatures $\left({ }^{\circ} \mathrm{C}\right)$ in three different types of artificial burrows (soil, plastic and concrete) on Nonsuch Island and ambient May-June 2004.

Data from this study indicate a return rate of non-translocated Bermuda Petrel fledglings of at least $59 \%$. Recruitment data from other Procellariiformes are scant, largely because the likelihood of finding returning birds among the multitude of pairs within large colonies is low; consequently return rates are likely to be severely underestimated. Accurate data are likely to be obtained only from small isolated colonies, where all or most nest sites are known. Data collected over 11 years (1950-1960) at the small colony of Short-tailed Shearwater Puffinus tenuirostris on Fisher Island, Australia, indicate that the return rate of fledglings is $37 \%(n=522)$, with birds first returning when 2-7 years of age (Wooller et al. 1990).

Based on a return rate of $59 \%$ we expect that from the 101 translocated birds that fledged, 60 would return to Bermuda within 8 years. So far 24 have returned, of which 17 have returned to Nonsuch and seven have returned to one of the existing breeding colonies. Of the 55 individuals translocated in the first three cohorts (2004-2006), 15 have returned to Nonsuch Island, a return rate to date of $27 \%$, in a period of $4-6$ years. Although likely to increase further, this is already a high rate of return compared to translocations of other Procellariiformes (see review by Miskelly et al. 2009). The gender of translocated or returned fledglings is unknown, so no assessment of sex ratios of returned birds is possible.

For Procellariiformes, fledgling mass can affect future recruitment, with heavier birds more likely to return to the colony (Perrins et al. 1973, Sagar and Horning 1998). For some species, this same relationship has been found to extend to translocated individuals (Miskelly and Taylor 2004, Bell et al. 2005). Bermuda Petrel nestlings that were translocated in 2004 fledged 
about $50 \mathrm{~g}$ lighter and went to sea about 5 days earlier than normal. The low return rate of this cohort may well be a consequence of their low fledging weight. Feeding larger meals to subsequent cohorts of translocated birds resulted in substantially heavier fledglings and higher rates of return.

Few translocation programmes involving Procellariiformes have adequately searched for translocated birds back at the donor colony. This study was unique, in that every potential nest site within all four donor colonies was repeatedly searched for the presence of returning birds, a task achievable only because of the limited extent of available nesting habitat and the intensive long-term monitoring programme in place for this species. In all, seven translocated birds have returned to the existing colonies. We could identify nothing distinctive about these birds, and the time between transfer and emergence of these individuals was similar to that of birds that returned to Nonsuch.

The first three translocated birds to return to Bermuda arrived before the audio system on Nonsuch was operational. These birds were discovered on Horn Rock, the largest of the four existing breeding colonies and less than $400 \mathrm{~m}$ from Nonsuch. Most attempts to establish new colonies of seabirds through translocation of nestlings have utilised recorded vocalisations to attract prospecting birds (Miskelly and Taylor 2004, Bell et al. 2005, Miskelly et al. 2009). However, the effectiveness of audio cues has not been experimentally evaluated and new seabird colonies have been established without the use of such devices (e.g. Priddel et al. 2006). In this instance, however, the absence of audio cues before February 2008 may have resulted in translocated birds being drawn elsewhere.

To date, only one non-translocated bird from the existing colonies has moved to Nonsuch Island. Elsewhere, new colonies of seabirds established by translocation or acoustic lures (or both) have attracted large numbers of birds from established colonies. For example, $76 \%$ of Gould's Petrels forming a new colony on Boondelbah Island came from existing colonies (Priddel et al. 2006). Similarly, $80 \%$ of Common Diving Petrels in the new colony on Mana Island and $20 \%$ of Fluttering Shearwaters on Maud Island were immigrants (Miskelly and Taylor 2004, Bell et al. 2005, Miskelly et al. 2009).

Although all artificial burrows on Nonsuch Island were partially shaded by vegetation, maximum temperatures within these burrows exceeded temperatures inside nearby soil burrows by a few degrees. Heat stress resulting from elevated temperatures in artificial plastic burrows is thought to have caused the deaths of a third of all Great-winged Petrels Pterodroma macroptera involved in a trial translocation at Mount Maunganui, New Zealand (Miskelly et al. 2009). Potentially, high temperatures at the onset of summer could be a problem for late-fledging Bermuda Petrel nestlings. Birds that use soil burrows will be less exposed to temperature extremes than those that use artificial burrows. To date, all returning birds have opted to use concrete burrows, although some have excavated large amounts of soil from around the entrance to the burrow. To encourage nesting in soil burrows, the plastic burrows on Nonsuch Island have been removed and shallow soil burrows dug in their place. Nesting in soil burrows will alleviate the need to construct more concrete burrows.

The translocation of Bermuda Petrel to Nonsuch Island has resulted in the first breeding of the species on this island in more than 300 years. Up to the end of the 2009/1o breeding season, a total of 18 adults have been recorded at the new colony, five eggs laid and two fledglings produced. As it may take 7 years or longer for some Bermuda Petrels to return to breed (Tables 4 and 5), more translocated birds are expected to join the colony over the next few years. The first appearance of a non-translocated bird on Nonsuch Island colony in 2009 is encouraging, and based on experience elsewhere we expect more non-translocated birds to join the colony. The successful establishment of a breeding population of Bermuda Petrel on Nonsuch Island, where nest sites are protected from storm damage, greatly improves the conservation prospects of this Endangered species, and demonstrates the importance of translocation as a tool for the conservation of threatened seabirds. 


\section{Acknowledgements}

The efforts and support of the following people have contributed to the recent successes of the recovery programme: Jack Ward, Jennifer Gray, Leila Madeiros, Annie Glasspool, Patrick Talbot and Joseph Furbert. The Bermuda Terrestrial Conservation Work Crew consisting of Barry Smith, Hillgrove Iris, Kiwon Furbert and Marvin Jones installed the artificial burrows on Nonsuch Island. Chris Flook (Bermuda Aquarium, Museum and Zoo) provided fresh fish for the translocated nestlings. The Bermuda Weather Service provided daily temperature data. Deidre Brennan (Castletown Productions) provided essential night vision equipment. The Bermuda Audubon Society provided funding for all other equipment. Robert Wheeler, Colin Miskelly and Graeme Taylor provided constructive comments on an earlier draft of this paper.

\section{References}

Bell, M., Bell, B. D. and Bell, E. A. (2005) Translocation of fluttering shearwater (Puffinus gavia) nestlings to create a new colony. Notornis 52: 11-15.

Butler, N. (1619) Historye of the Bermudaes. In J. H. Lefroy, ed. Memorials of the discovery and early settlement of the Bermudas or Somers Islands 1515-1652. Compiled from the Colonial Records and other original sources. Vol. 1. (1877). London: Longmans, Green and Co.

Emanuel, K. (2005) Increasing destructiveness of tropical cyclones over the past 30 years. Nature 436: 686-688.

Gangloff, B. and Wilson, K-J. (2004) Feeding frequency, meal size and chick growth in Pycroft's petrel (Pterodroma pycrofti): preparing for chick translocations in Pterodroma species. Notornis 51: 26-32.

Imber, M. J., McFadden, I., Bell, E. A. and Scofield, R. P. (2003) Post-fledging migration, age of first return and recruitment, and results of inter-colony translocation of black petrels (Procellaria parkinsoni). Notornis 50: 183-190.

IUCN (2010) IUCN Red List of threatened species. Version 2010.1. http://www.iucn redlist.org (acceessed on 3 February 2010).

Madeiros, J. (2005) Recovery plan for the Bermuda Petrel (Cahow) Pterodroma cahow. Bermuda: Department of Conservation Services.

Madeiros, J., Carlile, N. and Priddel, D. (2012) Breeding ecology and population increase of the endangered Bermuda Petrel Pterodroma cahow. Bird Conserv. Internatn. 22: 35-45.
Miskelly, C. M. and Taylor, G. A. (2004) Establishment of a colony of Common Diving Petrels (Pelecanoides urinatrix) by chick transfers and acoustic attraction. Emu 104: 205-211.

Miskelly, C. M., Taylor, G. A., Gummer, H. and Williams, R. (2009) Translocations of eight species of burrow-nesting seabirds (genera Pterodroma, Pelecanoides, Pachyptila and Puffinus: Family Procellariidae). Biol. Conserv. 142: 1965-1980.

Murphy, R. C. and Mowbray, L. S. (1951) New light on the Cahow, Pterodroma cahow. Auk 68: 266-280.

Perrins, C. M., Harris, M. P. and Britton, C. K. (1973) Survival of Manx Shearwaters Puffinus puffinus. Ibis 115: 535-548.

Priddel, D. and Carlile, N. (1995) An artificial nest box for burrow-nesting seabirds. Emu 95: 290-294.

Priddel, D., Carlile, N. and Wheeler, R. (2006) Establishment of a new breeding colony of Gould's petrel (Pterodroma leucoptera leucoptera) through the creation of artificial nesting habitat and the translocation of nestlings. Biol. Conserv. 128: 553-563.

Sagar, P. M. and Horning, D. S. Jr. (1998) Mass-related survival of fledgling Sooty Shearwaters Puffinus griseus at The Snares, New Zealand. Ibis 140: 329-331.

Strachy, X. (1625) Letter to an excellent Lady in Hakluytus Posthumus or Purchas His Pilgrimes. S. Purchase, ed. Contayning a history of the world in sea voyages, and lande-Trauells, by Englishmen and others. London: Hakluyt Society. 
Tennyson, A. J. D. and Taylor, G. A. (1990) Behaviour of Pterodroma petrels in response to "war-whoops". Notornis 37: 121-128.

Wingate, D. B. (1978) Excluding competitors from Bermuda petrel nesting burrows. Pp. 93-102 in S. A. Temple, ed. Endangered birds: management techniques for preserving threatened species. Madison, USA: University of Wisconsin Press.

Wingate, D. B. (1985) The restoration of Nonsuch Island as a living museum of Bermuda's pre-colonial terrestrial biome. Pp. 225-238 in P. J. Moors, ed. Conservation of island birds. Cambridge: International Council for Bird Preservation.
Wingate, D. B. (1988) The restoration of an island ecology. Whole Earth Rev. Fall: 42-57.

Wooller, R. D., Bradley, J. S., Skira, I. J. and Serventy, D. L. (1990) Reproductive success of short-tailed shearwater Puffinus tenuirostris in relation to their age and breeding experience. J. Anim. Ecol. 59: 161-170.

Wurster, C. F. Jr. and Wingate, D. B. (1968) DDT residues and declining reproduction in the Bermuda Petrel. Science 159: 979-981.

Zar, J. H. (1974) Biostatistical analysis. Englewood Cliffs, N J: Prentice Hall.

Zimmerman, D. R. (1975) To save a bird in peril. New York: Coward, McCann and Geoghegan Inc.

\section{NICHOLAS CARLILE, DAVID PRIDDEL*}

Office of Environment and Heritage, PO Box 1967, Hurstville, NSW 2220, Australia.

\section{JEREMY MADEIROS}

Department of Conservation Services, Ministry of the Environment, PO Box FL588, Flatts, FL BX, Bermuda.

${ }^{*}$ Author for correspondence; email: david.priddel@environment.nsw.gov.au

Received 7 April 2011; revision accepted II July 2011 